\title{
READOUT THE PRINCIPLES OF COMPACT CITY IN THE NEIGHBORHOODS OF THE IRANIAN CITIES (CASE STUDY: NAZI ABAD NEIGHBORHOOD OF TEHRAN)
}

\author{
Khatereh Ahsani \\ Master's degree in architecture, Member of Elite and Young Researchers Club, Islamic Azad \\ University of Nour, Iran \\ Kha.ahsani@gmail.com
}

Ali Asgharzadeh

$\mathrm{PhD}$ in Architecture, Faculty member, Islamic Azad University of Nour, Nour, Iran ali_asgharzadeh4@yahoo.com

\begin{abstract}
City is the manifestation of human culture and civilization. Urban neighborhoods as social spaces play an important role in the lives of citizens. Texture density in neighborhoods, concentration of complex land uses and their proximity to each other are closely associated with sustainable urban forms. Today, with the increase of urban population, we are observing transformation and destruction of urban neighborhoods and a lot of old neighborhoods are being destroyed under the pretext of having timeworn texture and lack of accountability to our urban population. Tehran metropolis is no exception to this. Here we encounter two urban problems: First, uncontrolled urban dispersion and second, a huge amount of buildings which haven't any identification and have formed regardless of their field bed. Compact city is a model of sustainable cities and this is an efficient model to address the phenomenon of urban dispersion. In addition, the model emphasizes the focus on the neighborhood. Nazi Abad neighborhood in Tehran, one of the old quarters of the city that has a compact and outdated texture. In recent years, new buildings are being built in the neighborhood, which were formed regardless of the identity and the dominant pattern in this neighborhood. This had a negative impact on the neighborhood and has tarnished its image. By using descriptive-analytic study as well as field studies on Nazi Abad neighborhood, this paper considers this neighborhood as part of the skeleton of Tehran and aims to solve these urban problems by providing some solutions and identify the patterns in Nazi Abad neighborhood. The contents listed in this article aims to provide key tools for urban planning, urban identity and locations for future designs.
\end{abstract}

Keywords: compact city, neighborhood-oriented, sustainable, Nazi Abad neighborhood

\section{INTRODUCTION}

As a manifestation of human civilization, city is a settlement which was selected by humans for a better and more deserving elements. In fact, the world has gone towards urbanization for centuries (United Nations 2001; United Nations center for (human settlements [1996] 2000). With the passage of time and the creation and development of new technologies, the form of cities has changed. While most manufacturers pay less attention to the importance of urban space and distance due to the consequence of globalization and the spread of communication (cairncross, 2001), other thinkers have pointed to the importance of proximity and economic benefits of urban density. In between these two poles, a problem that is emerging is massive migration to urban areas and rapid population growth, urbanization, suburban dispersion and decentralization in the cities, especially the metropolises. In the second half of the 20th century phenomenon of urban sprawl, with a widespread lack of decentralization appeared in cities and spread outwards. Factors that were a result of urban sprawl, 
are: More car ownership, weaker public transport services, walking and cycling and reduce excessive growth in construction and the like as far as the population declined and this state affects quality of urban life, community, environment economic and social dimension (jenks, Burton, Williams.1996). This phenomenon is the result of migration and urbanization, rapid population growth in recent years, most cities are also put at risk. Therefore, presenting Strategies aimed at enhancing the quality of life in cities and neighborhoods is essential. In order to achieve this goal, we need an urban model that focuses on centralization instead of decentralization. As we know, there is a direct relationship between urban form and spatial structure of urban neighborhoods. Therefore, to achieve sustainable urban form, you must first start from urban neighborhoods. Nazi Abad is one of the old neighborhoods with a compact texture and because of its ancient culture, it is known as "the heart of Tehran". In recent years, many old houses and buildings in Nazi Abad have been replaced by new buildings and most of them have no identity. This had an adverse impact on the urban environment in Nazi Abad, regardless of compact patterns, because the traditional context in Nazi Abad had been formed in compact and layered manner. Hence, this paper aims to examine the current situation in Nazi Abad neighborhood and explain them aimed at designing a compact city.

Therefore, this article is aimed to answer the following questions:

What is the concept of a compact city?

What are the compact dimensions in Nazi Abad neighborhood?

\section{RESEARCH METHODOLOGY}

These research is descriptive - analytic. Initially, citing the available resources, principles and concepts of urban compact in urban areas were evaluated. Then using field studies and observation and making photos, the compact dimensions in the study area (Nazi Abad neighborhood of Tehran) were studied.

\section{BASIC DEFINITIONS}

\section{URBAN SUSTAINABILITY}

Urban sustainability is the idea in which a city can be organized in order to be able to adapt to renewable resources it is comfortable to live in terms of economic, social, and environmental and so on. The main objective is to create a place to reduce pollution and optimal use of the land. This includes social justice and quality of life. Economically, this would provide employment opportunities, adequate facilities, saving energy, time, individual and collective costs (Ahsani, Asgharzadeh: 2014).

In general, urban sustainability has a triple dimension which are shown in Figure 1: 


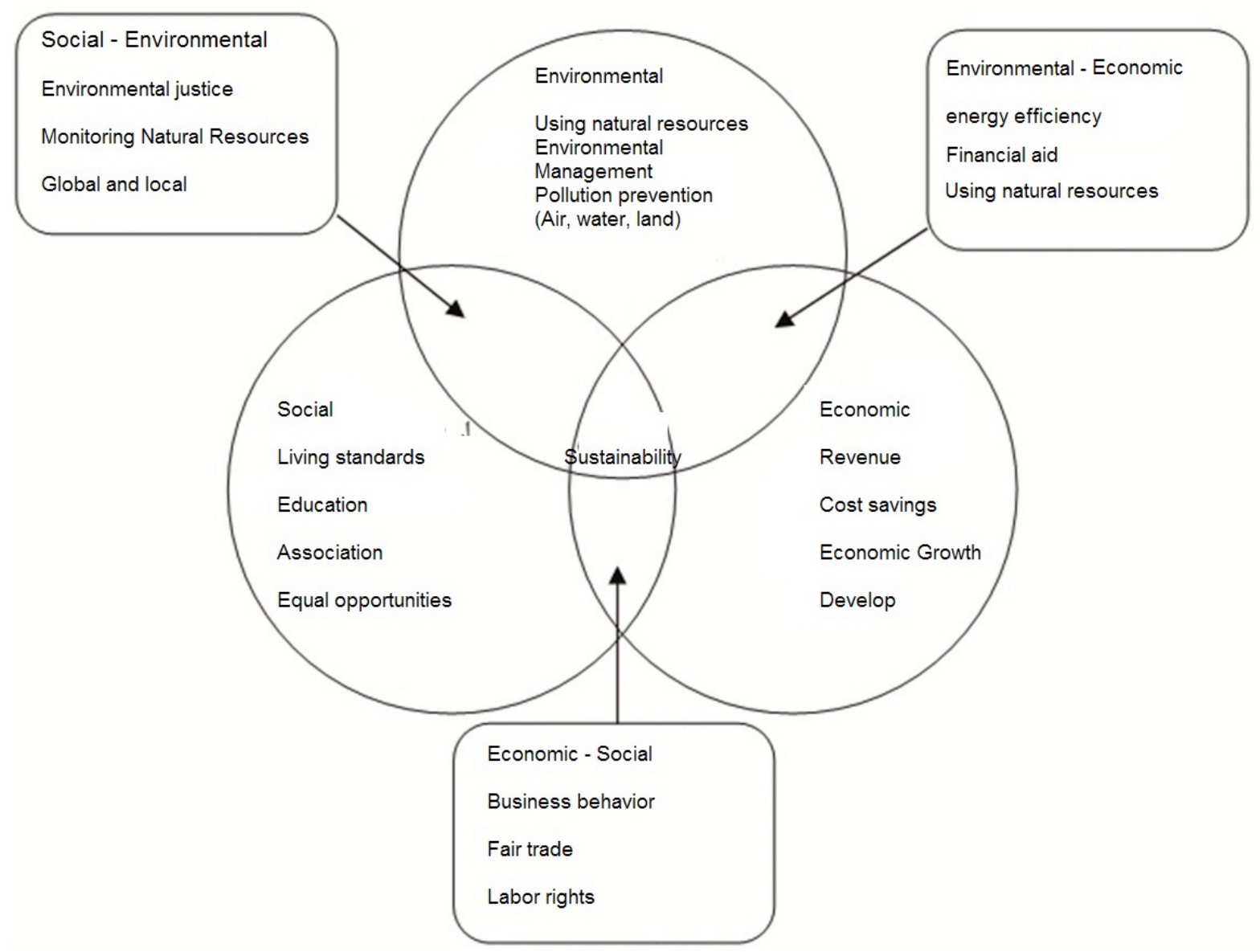

Figure 1: The three dimensions of urban sustainability; resource: Adopted from the 2002 University of Michigan Sustainability Assessment

\section{DENSITY}

Density of the built environment is a widely accepted strategy through which sustainable urban forms can be obtained. Urban density refers to proximity and connection and shows that the future of urban development should occur in the vicinity of the existing urban structure (Wheeler, 2002). The density of urban space can minimize the transportation of energy, water, materials, goods and people.

An important strategy to achieve compression is effective use of urban land by increasing the density of development and activity. Intensified form of construction involves the development of undeveloped urban land, existing buildings or redevelopment of previously developed land, which is divided into and additions and extensions (Jenks, 2000).

\section{THE CONCEPT OF COMPRESSION}

\section{COMPACT CITY}

Before the international promotion of sustainable development, the idea of "radiant city" was proposed by Le Corbusier as a solution to urban problems during the reign of Queen Victoria. Following the ideas of Le Corbusier in connection the radiant city, Dantzing and Saaty (1973) offered the compact city (Dantzing and Saaty, 1973). Their perspectives was based on enhancing the quality of life but not at the expense of "next generation" (ibid: 10). The so-called compact city is a concept quite the opposite in comparison with the concept of urban sprawl. The compact city is more efficient and less polluting. Residents have access to more services and stores and can walk, bike and transportation would be easier. Proponents claim that these cities can promote community-based social patterns (Katz, 1994). 
Compact cities represent a unique reaction in order to solve many urban problems such as land use in outskirts, increase resources of waste production, air pollution, and social segregation and so on; and this reaction is synonymous with sustainable city (Neumann, 2005: 17). We can say that urban sustainability requires a balance with the environment and identify existing and potential areas to create a suitable spatial structure. But urban planning evolved during the twentieth century, resulting in a variety of forms in their cities that often pay little attention to environmental impact and spatial structure within the cities. Considering the natural and artificial environment is the main ingredient in the compact city (Ahsani, Asgharzadeh, 2014).

\section{COMPRESSION PARAMETERS IN THE COMPACT CITY}

Given the importance of the compact city, Europe Commission and national governments in many Western countries intend to focus on compact cities to reduce pollution and energy consumption (Breheny, 1996). In fact, the population of Europe and Agenda 21 declared that "the development with high-density as a basic principle for urban growth "is an important requirement (De Roo, 2000). Before the international promotion of sustainable development, the idea of "radiant city" was proposed by Le Corbusier as a solution to urban problems during the reign of Queen Victoria. Following the ideas of Le Corbusier in connection the radiant city, Dantzing and Saaty (1973) offered the compact city (Dantzing and Saaty, 1973). Since then, the concept of compact city was formed as a pioneered concept in urban planning, especially in Europe (Haußermann \& Haila, 2004). Dantzing and Saaty (1978) were the first ones who attempted to define the compact city and explain the characteristics of compact urban form and space with the features and functions of their community. Table 1 illustrates this index:

Table 1: characteristics of compression from the perspective of Dantzing and Saaty

\begin{tabular}{|r|r|r|}
\hline Urban form & Spatial features & social factors \\
\hline High-density housing & Mixed land use & social justice \\
\hline $\begin{array}{r}\text { Less Dependence on Cars } \\
\text { Have a transparent border from } \\
\text { the surrounding area }\end{array}$ & Diversity of life & $\begin{array}{r}\text { Self-sufficiency from everyday } \\
\text { life }\end{array}$ \\
\hline
\end{tabular}

Source: Adapted from Hideki, 2003

The compact city paradigm is not only based on the concept of efficient use of land and urban area, but also it includes the objectives and parameters that are associated with sustainable urban form. Some of these factors include: (Williams, 1999)

The urban area separated from the residential area, which is the productivity of the used land

Sustainable public transport, less dependent on the car, less climate change, lower travel costs and public health benefits of non-motorized trips

Protect the countryside, farmland, ecological diversity

Focus on urban neighborhoods with indirect social impacts such as social composition, social cohesion, economic diversification, etc.

Generally, compression in the city has three dimensions including density, mixed use and aggravation. Table 2 provides a description of these dimensions and their subdirectories:

Table 2: Three Dimensions of compression 


\begin{tabular}{|l|l|}
\hline The nature of the indices & Compact dimensions \\
\hline Density of characteristic nature & Density \\
\hline Individuals and households per hectare & population density \\
\hline $\begin{array}{l}\text { Individuals and households per hectare with the areas of citizenship in the } \\
\text { area }\end{array}$ & $\begin{array}{l}\text { Density of } \\
\text { construction form }\end{array}$ \\
\hline Density of in dense areas & $\begin{array}{l}\text { Density of sub- } \\
\text { centers }\end{array}$ \\
\hline $\begin{array}{l}\text { The percentage of residential buildings built with higher density and lower } \\
\text { large and small houses }\end{array}$ & Residential density \\
\hline The nature of combined index & Mixed use \\
\hline Key features and basic quality & Providing facilities \\
\hline $\begin{array}{l}\text { Variation in the number of facilities in each section, and dividing by the } \\
\text { average number of possibilities in that sector }\end{array}$ & $\begin{array}{l}\text { Combination / } \\
\text { separation facilities } \\
\text { in the horizontal } \\
\text { plane }\end{array}$ \\
\hline $\begin{array}{l}\text { Development of retail / residential and commercial / residential } \\
\text { development }\end{array}$ & Vertical mixed use \\
\hline Nature of Intensification indices & Intensification \\
\hline The rate of internal migration & Population increase \\
\hline $\begin{array}{l}\text { The rate of new residential buildings, changes in the proportion of small } \\
\text { and large houses, rehabilitation of abandoned land and planning approval }\end{array}$ & $\begin{array}{l}\text { Increased } \\
\text { development }\end{array}$ \\
\hline Changes in the density of the dense area & $\begin{array}{l}\text { Increase in the } \\
\text { density of sub- } \\
\text { centers }\end{array}$ \\
\hline
\end{tabular}

Source: Burton, 2008

\section{NEIGHBORHOOD-ORIENTED IN THE COMPACT CITY URBAN NEIGHBORHOODS}

Neighborhood is one of the most physical divisions in the city. In the past, neighborhood plays an important role in urban areas and objectify its role in contemporary times. The concept of neighborhood has meanings, functions and values that they can be examined at various levels and dimensions. Henri Lefebvre described the neighborhood as an organized form of urban space, and acknowledges that neighborhood organized by social forces (Rabbani, 2002).

In the specialized studies that examined the concept of neighborhood, there are two main attitudes regarding the neighborhood:

A. neighborhood as a physical-spatial unit: In this approach, with an emphasis on spatial concepts, the neighborhood is made up of physical elements such as residential units, communication services and networks that settlement and collection of related activities occur in different spaces of the neighborhood. In such an attitude, neighborhood can create context for relationships and social ties between residents. West neighborhood concept with an emphasis on physical-spatial can become meaningful with such an attitude. In this perspective, Neighborhood can be defined by an index function and borders of neighborhood are determined by the radius of activity performance in this function. Like neighborhoods that are defined by urban planning through the area of school performance. In addition, the neighborhood is defined by its relationship with one or more service organizations or local organs. Like neighborhoods that be defined by the electoral districts, police stations, parks, public transport network, social services and cultural areas covered by the local administration and municipalities or their boundaries (Shi'a, 2003; Saeidnia, 2006).

B. neighborhood as social and physical-spatial unit: 
In this view, social and physical-spatial both involved in the definition of neighborhood. This attitude considers neighborhood a more comprehensive concept than the previous approach. Social concept of neighborhood is defined by a set of communication and social interaction. Neighborhood is a primary form of social organization and include those who have shared history. Action and interaction in the neighborhood Creates a sense of belonging and cooperation. In the history of urbanization in Iran, there was a strong social attitude to neighborhood (Ashraf, 1973; Soltanzadeh, 1989; tavassoli, 1997).

\section{NEIGHBORHOODS AS URBAN COMPACT CELLS}

Urban neighborhoods of the city act as small cell and they are confluence of social, economic aspects and urban space in the small scale of city. Lynch described the neighborhood as such: "a relatively large area of the city that have similar characteristics and are consistent regulatory practice and be able to enter it" (Lynch, 1997). In the compact city model, neighborhoods act as individual cells. "Neighborhood cell" is an urban compact cell which provides favorable conditions and people can reach their destination by walking in about 20 minutes. In addition, the neighborhood cells have a small electrical network which provides heating, power, communication networks and others in the community. And yet, this is linked with other communities and is connected to the transport network. Within the urban compact cells, there is the future structure of the city according to a number of design principles where it is allowed to increase density with increasing vitality and viability of city (IFHP, 2013). Figure 2 shows a model of urban compact cell configuration that is associated with the viability of the concept of "neighborhood cell" as a basis for the development has been introduced in the future.

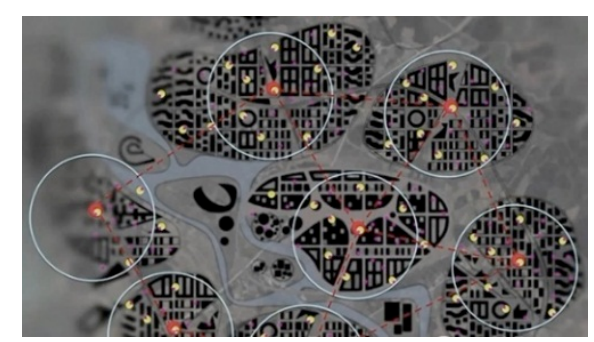

Figure 2: urban compact cell configuration; Source: IFHP, 2013

According to the above definitions, the concept of compression in the neighborhood-oriented dimension and urban neighborhood compact cells included multiple dimensions. Hence, we found six important features in the compact urban neighborhoods that are mentioned in Table 3:

Table 3: The concept of compression in the neighborhood-oriented dimension in the compact city

\begin{tabular}{|l|l|l|l|l|l|}
\hline \multicolumn{3}{|c|}{ The concept of compression in the neighborhood-oriented dimension in the compact city } \\
\hline $\begin{array}{l}\text { first } \\
\text { indicator }\end{array}$ & $\begin{array}{l}\text { Second } \\
\text { characteristic }\end{array}$ & Third index & $\begin{array}{l}\text { Fourth } \\
\text { indicator }\end{array}$ & Fifth features & Sixth feature \\
\hline walkability & $\begin{array}{l}\text { Mixing land } \\
\text { uses }\end{array}$ & $\begin{array}{l}\text { Connection with } \\
\text { surrounding } \\
\text { neighborhoods }\end{array}$ & $\begin{array}{l}\text { Multicenter } \\
\text { density }\end{array}$ & $\begin{array}{l}\text { Density in the } \\
\text { neighborhood } \\
\text { tissue }\end{array}$ & $\begin{array}{l}\text { Space status } \\
\text { in the } \\
\text { neighborhood }\end{array}$ \\
\hline
\end{tabular}

Source: authors

\section{THE INTRODUCTION OF THE STUDIED AREA}

Nazi Abad neighborhood (Madain) is one of the neighborhoods in south of Tehran, located in the 2nd District of Region 16 of Tehran and it is totally 18 square kilometers and more than 600 thousand people live in this populated area. The nearest neighborhood of the old neighborhoods of Tehran is Khanyabad Nou which is located in southwestern of Nazi Abad. In the south, Nazi Abad is limited by Reye town, in the East, this is limited to Railway Square and in the West, and this is limited to 
Ghal'eh Morghi Fortress (uni17.blogfa.com). The neighborhood leads to Azadegan Highway in the south, this leads Be'sat Highway in the north, this leads to Rajaee Highway in the East and this leads to Tondgoyan highway in the West. This area has been developed from the Qajar era. But the neighborhood fundamental systematic planning be introduced in line with modernizations of the first Pahlavi and this plan was prepared by German consultants and came into force during the second Pahlavi. Land in the northern part were used to build a factory and people settled in southern and central sectors. This neighborhood has seventy-two squares that there is a lot of public space between all quarters (Mansoor Rezaee \& Esmaily, 2010). Nazi Abad is one of the old neighborhoods with a compact texture and because of its ancient culture, it is known as "the heart of Tehran".In recent years, many old houses and buildings in Nazi Abad have been replaced by new buildings and most of them have no identity. This had an adverse impact on the urban environment in Nazi Abad, regardless of compact patterns.

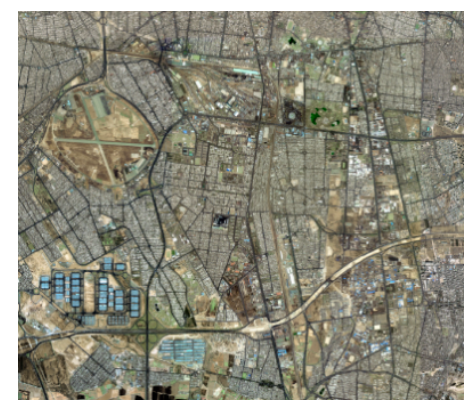

Figure 3: Range of Nazi Abad neighborhood in 16th region of Tehran; Source: Google earth

\section{CHECK COMPRESSION IN NAZI ABAD NEIGHBORHOOD}

The study was conducted in Nazi Abad. Nazi Abad is divided into 8 small neighborhood. After reviewing the neighborhoods and taking into account the location, the importance and social status within the range was chosen. The study area covers an area of 19668 square meters and from the North and South and East and West, it is restricted by streets of Akbar Mashadi, martyr Khaleghipour, Kargar Samani and Khalili. In this research, the concept of compression were investigated in this neighborhood. Thus, this study performed according to six criteria listed in Table 3 and using field studies, observation and sketch. The results are shown in Table 4 .

Table 4: the concept of compression in Nazi Abad

\begin{tabular}{|l|l|l|l|}
\hline \multicolumn{2}{|l|}{ the concept of compression in Nazi Abad } & Explanations \\
\hline No. & Index & Image & $\begin{array}{l}\text { Lack of attention to pedestrian and } \\
\text { bicycle path - inappropriate } \\
\text { distribution of land use compared to } \\
\text { walking paths }\end{array}$ \\
\hline 1 & $\begin{array}{l}\text { Malkability } \\
\text { uses }\end{array}$ & $\begin{array}{l}\text { Lack of mixing land uses equally in all } \\
\text { parts of the neighborhood }\end{array}$ \\
\hline
\end{tabular}




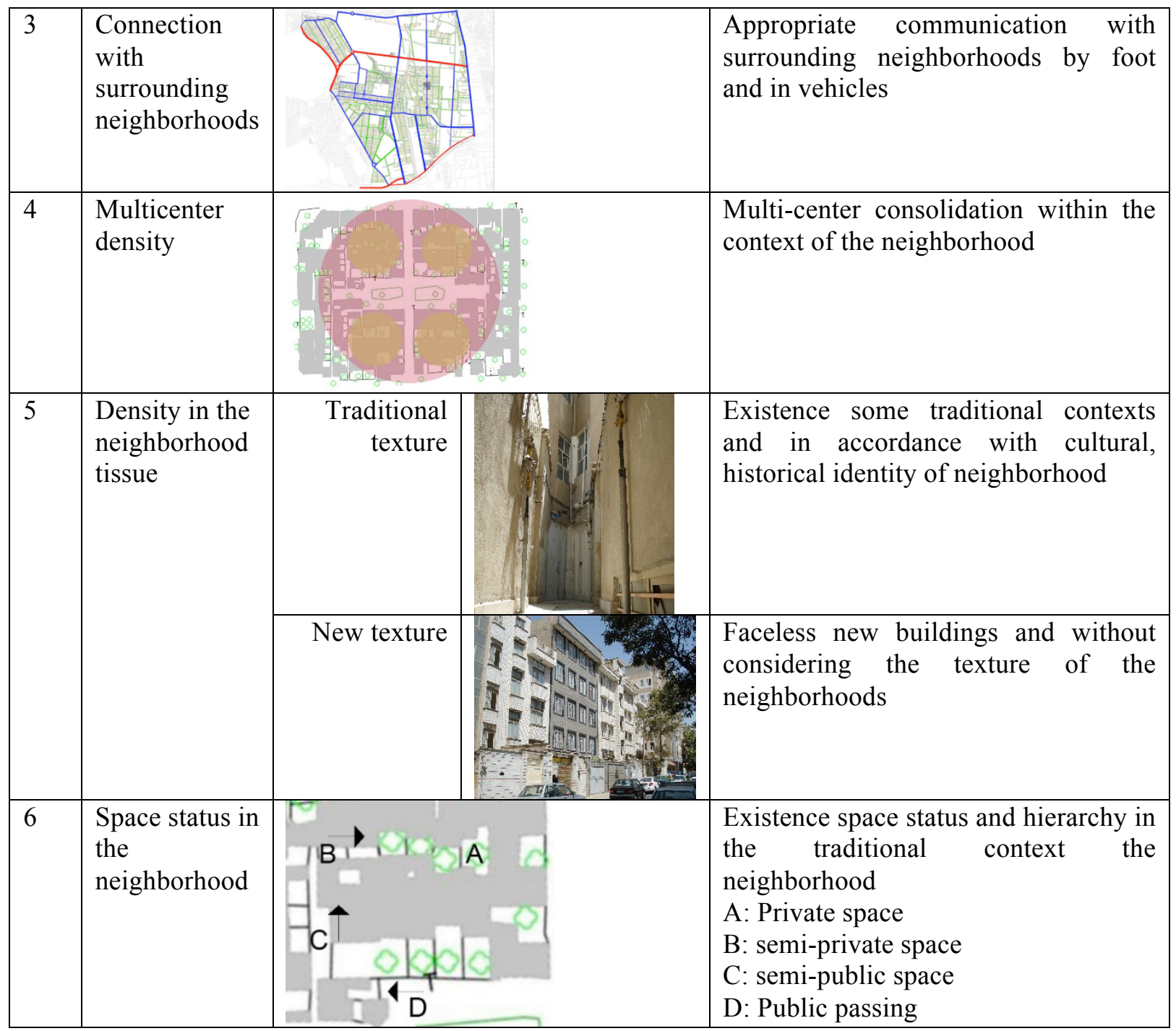

\section{ANALYSIS OF THE RESULTS}

In the previous section, the Nazi Abad neighborhood was studied in terms of six factors of compression. Some of these six factors highlighted in this range and others are less visible. After review, the proposed solutions are analyzed and presented. The findings suggest that Nazi Abad neighborhood has a compact texture and compression factors can be seen in urban neighborhoods.

Table 5: strategies and proposals in relation to the characteristics of axial compression in Nazi Abad

\begin{tabular}{|l|l|l|}
\hline No. & Index & Strategies and recommendations \\
\hline 1 & walkability & $\begin{array}{l}\text { Create a defined path for pedestrians and bikes accessible location } \\
\text { within walking distance of some land uses close to home }\end{array}$ \\
\hline 2 & Mixing land uses & $\begin{array}{l}\text { Existence of blocks with different uses such as commercial and } \\
\text { administrative, residential In different parts of the neighborhood }\end{array}$ \\
\hline 3 & $\begin{array}{l}\text { Connection with } \\
\text { surrounding } \\
\text { neighborhoods }\end{array}$ & $\begin{array}{l}\text { improve zoning at the local level, according to the principle of } \\
\text { social relationships and improve the quality of urban life }\end{array}$ \\
\hline 4 & Multicenter density & Allows mixing of different land uses in various local centers \\
\hline 5 & $\begin{array}{l}\text { Density in the } \\
\text { neighborhood tissue }\end{array}$ & $\begin{array}{l}\text { Pay more attention to the underlying tissue and neighborhood } \\
\text { identity and modernization and improvement of the existing fabric } \\
\text { according to traditional media viewing buildings accordance with }\end{array}$ \\
\hline
\end{tabular}




\begin{tabular}{|l|l|l|}
\hline & & $\begin{array}{l}\text { the principles of district compression and comply with matching } \\
\text { materials in the neighborhood }\end{array}$ \\
\hline 6 & $\begin{array}{l}\text { Space status in the } \\
\text { neighborhood }\end{array}$ & $\begin{array}{l}\text { Fixed space in the context of the new neighborhood and a new } \\
\text { urban development and trying to continue this favorable trend }\end{array}$ \\
\hline
\end{tabular}

\section{CONCLUSION}

In modern times, despite the challenges of urbanization, especially in metropolises in Iran, understanding and using the contextual integration is important and undeniable. A successful, desirable and sustainable urban form should include urban contextual dimensions (economic, social, historical, environmental, etc.), so that all services and arrangements be considered with the goal of improving the quality of people's lives and well-being of the community.

The compact city concept that includes economic, social, environmental, etc., is a deserved and suitable model for Iranian cities with the aim of implementing urban planning policies for sustainable urban development. Because, despite the need for sustainable development in Iranian cities, most cities are suffering from the radical sprawl and spread in form and scope. And this caused tension and socioeconomic characteristics, it has been negative for society and the citizens and conversely, compact city model focuses on urban sustainability and centralization and starts from the neighborhood-oriented and gradually expand its own scope throughout the city. It also aims to create a sustainable urban form and spatial structure and seeking social justice and respect for citizens' rights and positive social interaction. Iran also has a rich culture and civilization history. Managers, architects and designers need to design a form and spatial structure in order to illustrate the rich history and culture in Iran. In this paper, the Nazi Abad neighborhood was evaluated in terms of compression. Six factors mentioned in the concept of Compression is indicative of this fact that Nazi Abad texture is dense and intensive, but solutions have been proposed to repair and rectify weaknesses in the neighborhood, which should be practiced carefully. Urban planners and managers should also be sure to apply interpretations.

\section{REFERENCES}

Ahsani, Kh., and Asgharzadeh, A. (2014), "we should stabilize the cities through compression", Second International Conference on Structural Engineering, Architecture and urban development, Tabriz

Ahsani, Kh., and Asgharzadeh, A. (2014), "compact city; a new model which is designed in cooperation with the Urban contextual form", the first international conference on advanced techniques in design and construction of contextual architecture, Tabriz

Ashraf, A., (1973), "characteristics of urbanization Iranian Islamic period", Journal of Human Sciences, Issue 4, Volume I, Tehran

Tavassoly, M., 1997, "the principles and methods of urban design and residential areas in Iran," Planning and Architecture Studies and Research Center, Tehran, Volume I, Fourth Edition

Rabbani, R. (2002), "urban sociology", SAMT publication, Tehran

Saeidnia, A., 2006, "Green Book for Guide municipalities (the urban centers and residential space)", the municipalities in the country, Tehran Second Edition

Soltanzadeh, H., 1989, "an introduction to the history of the city and urbanization in Iran", Amir Kabir, Tehran, Second Edition

Shi'a, A., 2003, "Introduction to Urban Planning", University of Science and Technology, Tehran, Thirteenth Edition

Lynch, Kevin (1997), The theory of city's good shape, translated by Seyyed Hossein Bahraini, Tehran, Helle / Tahan publication

Adopted from the 2002 University of Michigan Sustainability Assessment, http://www.eoi.es/blogs/sofiagarcia-carretero/, 2002. 
Breheny, M., "Centrists, decentrists and compromisers", in: M. Jenks, E. Burton \& K. Williams (Eds) The Compact City: A Sustainable Urban Form?, pp. 13-36 (London: E \& FN Spon), 1996 Burton Elisabeth .The Compact City: Just or Just Compact? A Preliminary Analysis, Urban Study Journal Limited, SAGE Publications, London, 2008.

Cairncross, F.,"The death of distance: How the communications revolution is changing our lives", Boston: Harvard Business School Press, 2001

Dantzing, George B., and Thomas Saaty. (1973). Compact city: A plan for a livable urban environment. San Francisco: W.H. Freeman.

De Roo, G, Miller, D,."Compact cities and sustainable urban development", Ashgate Publishing, London, 2000

Ha"ußermann, H. \& Haila, A., "The European city: A conceptual framework and normative project, in:Y. Kazepov (Ed)" , Cities of Europe: Changing Contexts, Local Arrangements and the Challenge to Social Cohesion, pp. 43-63 (Oxford: Blackwell Publishing), 2004

Hideki Kaji.,"Compact City as a Sustainable Urban Form", www.fasid.or.jp, retrieved January 2003 Jenks, M, Burton, E, Williams, K., "The Compact City. A Sustainable Urban Form?" , E \& FN SPON, London, 1996

Jenks Mike. The acceptability of urban intensification. In Achieving sustainable urban form, ed. Katie Williams, Elizabeth Burton, and Mike Jenks. London: E \& FN Spon, 2000.

Katz, P. (1994). The new urbanism: Toward an architecture of community. New York: McGraw-Hill. Neuman, M. (2005). The compact city fallacy, Journal of Planning Education and Research, 25(1), pp. 17

United Nations ( 1992). Agenda 21. New York: United Nations( 2001). "World urbanization prospects, the 1999 revision", NewYork: United Nations.

United Nations Centre for Human Settlements., "An urbanizing world: Global report on human settlements", In Urban future 21: A global agenda for twenty-first century cities, edited by P. Hall and U. Pfeiffer. London: E. \& F.N. Spon, . [1996] 2000

Wheeler, Stephen M. Constructing sustainable development/safeguarding our common future: Rethinking sustainable development, Journal of the American Planning Association 68 (1): 110-11, 2002.

Williams, K., "Urban intensification policies in England: Problems and contradictions, Land Use Policy", 16(3), pp. 167-178, 1999

www.uni17.blogfa.com 